\title{
Original article (short paper) \\ Relative age effect on the reaction time of soccer players under 13 years old
}

\author{
Eduardo Macedo Penna \\ Universidade Federal do Pará, Castanhal, PA, Brazil \\ Marco Túlio de Mello \\ Universidade Federal de Minas Gerais, Belo Horizonte, MG, Brazil \\ Renato Melo Ferreira \\ Universidade Federal de Ouro Preto, Ouro Preto, MG, Brazil \\ Luiz Carlos Couto de Albuquerque Moraes \\ Varley Teoldo da Costa \\ Universidade Federal de Minas Gerais, Belo Horizonte, MG, Brazil
}

\begin{abstract}
The relative age effect, which is the advantage obtained by an athlete born closer to the beginning of the selection year, has been shown to be an important variable in the development of soccer players. This study aimed to evaluate the influence of the season of birth on the choice reaction time (CRT) of elite soccer athletes in the under 13 years of age category. Seventy-six athletes participated who were $13.36 \pm 0.45$ years old. The volunteers were tested with a CRT test, and the results were divided according to the semester of birth (S1 or S2). We conducted a t-test in order to compare the results between groups and a Pearson correlation analysis to verify the associations between variables. The results indicated no differences in reaction time $(r=.033$ and $p=.772)$ or movement time $(r=.0073$ and $p=.530)$. It was concluded that for this population, the season of birth does not influence the performance of the capabilities tested.
\end{abstract}

Keywords: relative age effects, reaction time, cognition

Resumo - "A influência do efeito da idade relativa no tempo de reação em jogadores de futebol sub 13." O efeito da idade relativa, que consiste na vantagem obtida pelo atleta nascido mais próximo ao início do ano de seleção, tem se mostrado uma variável importante para o processo de seleção de esportistas. Este estudo objetivou avaliar a influência da época de nascimento no tempo de reação de escolha de futebolistas presentes nas categorias de base (sub 13) de clubes profissionais futebol. Participaram 76 atletas com idade de 13,36 0,45 anos. Os voluntários foram submetidos ao teste do TRE, e os resultados categorizados conforme o semestre de nascimento ( $\mathrm{S} 1 \mathrm{ou} \mathrm{S} 2$ ). Foi empregado o teste $\mathrm{t}$ para a comparação entre grupos, e análise de Correlação de Pearson para verificar a existência de associações entre as variáveis. Os resultados não indicaram diferenças entre os grupos no tempo de reação $(r=0,033$ e $p=0,772)$ e no tempo de movimento $(r=0,0073$ e $p=0,530)$. Concluiu-se que para essa população, a época de nascimento não influencia no desempenho dessa capacidade.

Palavras-chave: efeito da idade relativa, tempo de reação, cognição

Resumen - “La influencia del efecto de la edad relativa en el tiempo de reacción de jugadores de fútbol sub 13.” El efecto de la edad relativa, que consiste en el beneficio obtenido por el atleta nacido más cercano al inicio del año de selección ha sido una variable importante para el proceso de selección de los atletas. Este estudio tuvo como objetivo evaluarla influencia de la época de nacimiento en el tiempo de reacción de los jugadores presentes en los jóvenes (menores de 13) de los clubes de fútbol profesional. Participaron76 atletas de edad13,36 $\pm 0,45$ años. Los voluntarios fueron sometidos a la prueba de la TRE, y se clasificaron de acuerdo con el semestre de nacimiento (S1 o S2). Se utilizó el "teste t" para la comparación entre los grupos, y el análisis de correlación de Pearson para verificar la existencia de asociaciones entre variables. Los resultados indicaron que no hubo diferencias entre los grupos en el tiempo de reacción $(r=0,033$ e $p=$ $0,772)$ y el Tiempo de Movimiento ( $r=0,0073$ e $p=0,530)$. Se concluyó que para esta población, la fecha de nacimiento no influye en el rendimiento de esta capacidad.

Palabras clave: efectos relativos de la edad, tiempo de reacción, cognición 


\section{Introduction}

Soccer is one of the most popular sports in the world. In order to reach the professional level athletes need to improve the multiple factors that are determinants of their development, such as anthropometrical and physical traits (Gil, Ruiz, Irazusta, Gil, \& Irazusta, 2007; Reilly, Franks, \& Bangsbo, 2000), cognition (Vestberg, Gustafson, Maurex, Ingvar, \& Petrovic, 2012), and tactical and technical characteristics (Costa, Garganta, Greco, Mesquita, \& Seabra, 2010).

Among the many variables that could influence the development of the soccer athlete, the categorization of birth date, also known as birth quartile (Augste \& Lames, 2011; Delorme, Boiché, \& Raspaud, 2010), stands out. This variable is determined by dividing the months of the year into four equal periods as follows: the first quartile includes January to March, the second quartile includes April to June, the third quartile includes July to September and the fourth quartile includes the months from October to December (Costa et al., 2009; Vaeyens, Philippaerts, \& Malina, 2005). Others studies also have categorized the birthdates by the semesters of birth (Jullien, Turpin, \& Carling, 2008; Musch \& Grondin, 2001).

A number of studies of various sports that aimed to evaluate the categorization of athletes' dates of birth concluded that, in general, the distribution of these dates is not spread evenly throughout the year. Different studies showed this asymmetry in both team sports (Delorme \& Raspaud, 2009; Penna \& Moraes, 2010) and individual sports (Edgar \& O'Donoghue, 2006). In professional soccer, this asymmetry was demonstrated in different contexts and cultures (Costa et al., 2009; Coubley, Schorer, \& Baker, 2008; Jimenez \& Pain, 2008; Musch \& Hay, 1999; Simmons \& Paul, 2001; Vayens, Philippaerts, \& Malina, 2005 ) and was also shown on the basis of categories (Augste $\&$ Lames, 2011; Costa, Albuquerque, \& Garganta, 2012; Delorme \& Raspaud, 2010; Glamser \& Vicent, 2004; Helsen, Winckel, \& Williams, 2005; Romman \& Fuchslocher, 2011). For the variable of birth date category in soccer, it is also known that the higher the level of competition (elite versus non-elite), the higher is the presence of this birth date asymmetry (Mujika et al., 2009).

In general, these investigations concluded that athletes who were born closer to the beginning of the selection year (during the first and second quartiles) were overrepresented among the athletes, whereas those who were born later (third and fourth quartiles) were under represented. Therefore, this "advantage" obtained by the ones who were born earlier relative to the start of the selection year was called the relative age effect (Glamser \& Vicent, 2004).

Although there have been intense discussions about the relative age effect, they have been focused mostly on the presence or the absence of this variable in different sports. The studies that proposed to evaluate objectively the differences between the athletes who were born at different times of the selection year focused mainly on the biological maturation and aspects related to the athletes' physical attributes (Carling, Legall, Reilly, \& Williams, 2009; Hirose, 2009; Sherar, Baxter-Jones, Faulkner, \& Russel, 2007), thereby ignoring the importance of the percep- tive and cognitive attributes that contribute to athletic success.

Cognitive capabilities in sports can be conceptualized as the processes or structures that relate consciousness and knowledge (Dorsch, Häcker, \& Stapf, 2001). A great deal of success in athletic activities, especially in soccer, depends on the correct use of these processes. For example, during a soccer match, athletes are often required to react quickly to a visual and/or sound stimulus (the direction of the ball, movements and advances of other players, the whistle of the referee, the tendency of the coach to prefer a certain tactic, etc.) such that quick and correct judgment can influence not only the success of the particular maneuver but also the results of the matches (Spierer, Petersen, \& Duffy, 2010). Therefore, the requirement of an ability to react quickly to environmental stimuli makes this quality critical to the success of a soccer player. In light of this concept, the reaction time (RT) to visual and sound stimulus is frequently used as an indicator of an athlete's general ability (Hirose, Hirano, \& Fukubayashi, 2004). The RT can be conceptualized as the interval between the presentation of an anticipated stimulus and the beginning of the athlete's movement. This interval represents the accumulation of the three stages of information processing: identification, selection and response programming. The interval between the beginning and the end of the motor movement is called movement time (Schimidt \& Wrisberg, 2010). In addition, the RT can be differentiated into three types according to the number of stimuli and possible responses: simple, choice and discriminative (Magill, 2000).

It has been well described that the most highly skilled athletes demonstrate a better RT than athletes at lower skill levels (Harbin, Durst, \& Harbin, 1989; Hirose, 2011), and the RT in athletes is superior to that of non-athletes (Montes-Micó, Bueno, Canadel, \& Pons, 2000). Furthermore, the athletes' RT to visual stimulus is superior to the RT to sound stimulus, indicating that athletes rely more on "environmental visual clues" to anticipate their actions during the matches (Spierer et al., 2010). It is known that the RT was positively related to a propensity for success in young Japanese soccer players. According to Hirose (2011), the athletes who showed a better RT at 15 years of age achieved a higher Japanese competitive level, whereas those who showed a lower RT remained at the amateur levels.

Although athletes who were born earlier in the selection year are favored due to the relative age effects, we also may state that they benefit from having developed physical attributes in the early years of their athletic development (Carling et al., 2009; Hirose, 2009; Sherar et al., 2007). They also may benefit because of aspects related to the RT that will positively influence their athletic development process.

Despite the importance of investigating the relative age effect in soccer, no evidence was found about the RAE and its impact on soccer young athletes' reaction and movement time. This is especially important in the under 13 years of age category because this is the time when many of the selection and formation processes are started for these young athletes. Thus, the objective of this study was to verify the presence or absence of an association between the relative age effect (season of birth) and the reaction and movement time in elite soccer players in the under 13 years of age category. 


\section{Methods}

This study was approved by Minas Gerais Federal University's Ethical Committee under the ethics number ETIC 0221.0.203.000-11.

\section{Participants}

Seventy six male soccer players with an average age of $13.36 \pm 0.45$ years participated in this study and during the data collection while enrolled in the Minas Gerais State Soccer Federation and while participating at official competitions for the under 13 years of age category for the three main Minas Gerais formation teams ${ }^{1}$.

The under 13 years of age category was chosen because it represents the first competitive category with official national competitions recognized by the Brazilian Soccer Confederation $(\mathrm{CBF})$, and it also has been seen as the "competitive entrance door" for young athletes who want to become professionals.

The data were grouped according to the methods used in previous studies, (Julien, Turpin, \& Carling, 2008; Musch \& Grondin, 2001) and the test results (reaction time and movement time) were divided into two groups ( $\mathrm{S} 1$ and S2) according to the semester of birth of each volunteer. The S1 group's test results included all volunteers who were born in the first and second quartiles of the selection year, and the S2 group's test results included all volunteers who were born in the third and fourth quartiles of the selection year.

\section{Instruments}

A computerized test of choice reaction time was used to measure the RT. The test performed was part of Vienna's Test System $\AA$, and the version of the RT test used in this system was the "S7 Choice Reaction Time Version."

The RT version S7 test lasts approximately 5 minutes and begins with a familiarizing process which takes approximately 1 minute. The test begins after the familiarizing period during which any questions and errors are resolved. The test consists of a task on the computer screen during which different visual (red and yellow colors) and sound (bass sound) stimuli are presented to the volunteer. When the two specific stimuli are offered (1-red and yellow together and 2 - yellow and sound together), the volunteer is to take the forefinger off of the rest button and use that same finger to press the action button as quickly as possible. Volunteers are to ignore any of the other different stimuli combinations that were not the two pre-established ones (and not take the finger off of the rest button).

At the end of the test the equipment provides a report about the volunteer's decision making (right or wrong) performance and on reaction and movement times in milliseconds. The reaction time is the length of time between the beginning of the

\footnotetext{
${ }^{1}$ Teams that in the year of the study were playing in Brazilian's soccer first division.
}

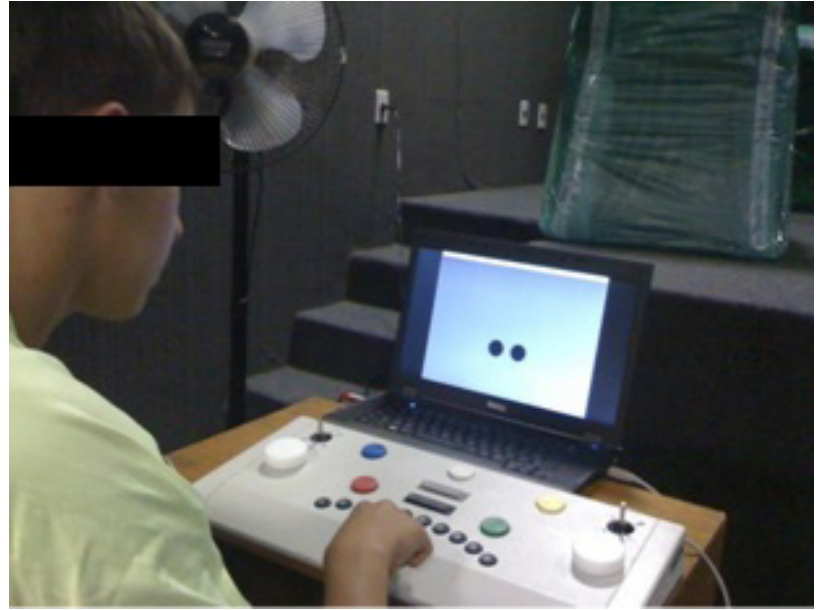

Figure 1. Reaction time test application.

presentation of the pre-established stimulus (red and yellow lights together, or yellow light and sound together) and the finger leaving the rest button, in other words, the time to process the stimulus. The movement time consists of the time interval between the finger leaving the rest button and the contact of the finger with the action button in response to the pre-established stimulus.

This type of test has been used in the athletic environment to evaluate the perceptive processes of athletes from different sports (Dogan, 2009; Noce et al., 2012).

\section{Procedures}

An initial contact was made with the teams to explain the methods and the objectives of the current study. After their approval was obtained, a meeting was held with each coach from the 13 years of age category to explain the procedures, to schedule the tests and to review the consent forms from the legal guardians.

The RT test version S7 was applied before the beginning of the training session to ensure that there was no interference of the training variables on the test results. The objectives and the procedures were explained and the consent forms were collected before the test was administered. During the test days a private room was reserved for the Vienna's Test System ${ }^{\circledR}$ setup to prevent outside interference during the test.

The equipment was calibrated, it was confirmed that none of the volunteers had previous experience with the RT version S7 test, and then all of the volunteers went through the familiarizing period. All of the procedures were performed by the same researcher.

The athletes' birthdates were collected from identification documents and birth certificates provided by the teams.

\section{Statistical analysis}

The individual results were grouped and then descriptive tests were performed on the performance of each group consis- 
ting of averages and standard deviations. To verify the normality and homoscedasticity of the data the Shapiro-Wilk test and the Levene test were used, respectively.

The Student's $t$ test was applied to compare the group results, and then a Pearson Correlation was used to evaluate the association between the variables of birth quartile and the performance test results. All tests were performed with the computer program SPSS 17.0 for Windows ${ }^{\circledR}$.

\section{Results}

\section{Reaction time tests}

The Shapiro-Wilk test indicated a normal distribution of the data and the Levene variance test showed that the variances presented by the groups were the same. The data referring to the reaction time result of groups $\mathrm{S} 1$ (born in the first semester) and S2 (born in the second semester) shown in Table 1indicate that the under 13 years of age soccer players evaluated did not have differences in RT, which relates to perception and processing.

The Pearson's correlation test results between the variables of the semester of birth and the cognitive RT test results showed no association between these two variables $(r=.033$ and $p=.772$ ).

\section{RT-Movement test's}

The Shapiro-Wilk test indicated that the movement time result showed a normal distribution of the data and the Levene variance test showed that the variances presented by the groups were the same. The data referring to the movement time result of groups $\mathrm{S} 1$ (born in the first semester) and S2 (born in the second semester) shown in Table 2 indicate that the soccer players under 13 years of age who were evaluated did not have differences demonstrated in this test.

The Pearson's correlation test results evaluating the variables of the semester of birth and the movement time test result also showed no association between these two variables $(r=.0073$ and $p=.530)$.

Table 1. Comparison of athletes' results of reaction time test (mean \pm $\mathrm{SD})$ for the semester of birth.

\begin{tabular}{lcc}
\hline Group & ReactionTime $(\mathbf{m s})$ & $\boldsymbol{P}$ \\
\hline $\mathrm{S} 1(n=56)$ & $608.51 \pm 68.06$ & .547 \\
$\mathrm{~S} 2(n=20)$ & $598.10 \pm 60.17$ & \\
\hline
\end{tabular}

Table 2. Comparison of athletes' results of movement time test (mean $\pm \mathrm{SD}$ ) for the semester of birth.

\begin{tabular}{lcc}
\hline Group & Movement Time (ms) & $\boldsymbol{P}$ \\
\hline $\mathrm{S} 1(n=56)$ & $177.10 \pm 38.16$ & \\
$\mathrm{~S} 2(n=20)$ & $188.90 \pm 46.06$ & .265 \\
\hline
\end{tabular}

\section{Discussion}

This study aimed to verify whether athletes who were born during different seasons of a competitive year exhibited differences in their reaction time and movement time. This study was motivated by previous scientific evidence that athletes who were born closer to the beginning of the competitive year had advantages that resulted in higher chances of achieving professional status (Augste \& Lames, 2011; Helsen et al., 2000; Simmons \& Paull, 2001; Penna, Santos, Ferreira, Costa, \& Moraes, 2012).

This question of the presence or absence of an association between the EIR and the cognitive capacity of reaction time becomes relevant. Regardless of the competitive category, soccer players are requested throughout the match to react cognitively and drive as fast as possible to take advantage of their opponents during the performance of motor actions on the field.

Despite the fact that few studies were found that directly related the RT to the consequences of the relative age effect, some discussion still is warranted. The only soccer study that directly correlated a variable that has a strong cognitive component with the relative age effects was performed by Costa et al. (2010), and which compared the tactical performance of athletes who were born in different quartiles of the competitive year by the test FUT-SAT. However, no strong correlation between the tactical performance and the time of birth was found in that study.

Therefore, despite the existence of different variables that may be related because the quality of the tactical behavior is also influenced by the performance of the reaction time and movement time, our current results confirm the aforementioned study by Costa et al. (2010). For the population of elite soccer athletes in the under 13 years of age category in Minas Gerais there were no differences in the RT measurements between athletes born in different semesters of the competitive year.

The results of the current study did not corroborate the proposition of authors who propose that age differences within the same category, which at most can represent almost a year in age difference between athletes in the same category, can lead to great differences in cognitive abilities (Jimenez \& Pain, 2008; Musch \& Hay, 1999). No difference between the semesters was noticed in the applied tests, and no association was identified between the birth quartile and the test performances as evaluated by the Pearson correlation test.

The results of reaction time, which measure the speed of processing a certain stimulus, can be discussed in the context of the study by Vänttinen et al. (2010) that showed that young elite soccer players performed better on reaction tests that "non-elite" athletes, and these results were connected to maturational issues. Because the current study evaluated only elite athletes belonging to the main Minas Gerais state team, it can be hypothesized that these athletes may already be in a cognitively advantaged state of maturation compared with non-selected athletes, thus justifying their presence on the team. It is described in the literature that coaches often choose athletes during the selection season who are in a more advanced maturational state (Helsen et al., 2000; Hirose et al., 2004).

Another possible explanation for the lack of difference found in the reaction and movement times may be related to training of the cognitive capabilities, as proposed by Voos, Kramer, Basak, Prakash, and Roberts (2010). In their study the authors state that 
cognitive abilities can be improved with systematic training and that their improvement is reflected in more efficient neural nets. However, according to Costa et al., (2010), athletes on elite teams benefit from better training conditions and have better possibilities for competitive experiences. Because the athletes in this study are in the beginning of their formation (the under 13 years of age category) and have limited systematic training time, it is possible to hypothesize that any improvement induced by the systematic and planned training was not caused by improvements in the transmission efficiency of neural net/networks (Voos et al., 2010). The literature also shows that older soccer players, such as in the under 20 years of age category and the professional category, show differences in reaction and movement time that are better than the average for the general population (Montes-Micó et al., 2000).

In addition, the athletes evaluated in the current study receive similar daily opportunities to develop themselves technically, physically, tactically and cognitively, independent of whether they were born closer to the beginning of the selection year or later in the year. This access to development opportunities can be particularly important for young athletes in the beginner's category, according to Hirose et al., (2004) who reported that cognitive capabilities develop rapidly during the transition from childhood to adolescence.

There are some limitations of this study that need to be mentioned, the first being the lack of utilization of additional tests related to reaction and movement time. The choice of not including other measurement tools was based on the fact that, prior to the current study, there were no scientific reports on the possible relationship of the EIR variables and cognitive and motor reaction tests of young soccer players in the first competitive category.

The second limitation relates to the use of laboratory tests that were not specific for the cognitive and motor tasks actually performed by the athletes on the field. This unfortunate reality has also been reported by other authors in the literature related to soccer (Ruschel et al., 2001). In order to be able to evaluate the "elite" Brazilian soccer players, in most cases researchers have to simplify their experiments to get access to these volunteers. Soccer coaches and managers also have a low awareness of the importance of these studies for the development of the sport, and a main argument is the lack of time for the teams to participate in this type of evaluation. These facts restrict possibilities for the study's procedures and limit the analysis and inferences of the results. In addition, the low ecological relationship with the sport-specific context also must be considered. However, the "cognitive component skills approach" cited by Voss et al. (2009) shows relevance in the athletic context. This type of research examines the relationship between athletic expertise and performance on measures of cognition that presumably tap into some of the fundamental cognitive demands of competitive sport training (Nougier, Stein, \& Bonnel, 1991). Thus, as cited by Voss et al. (2009), this approach has important implications for capturing and characterizing the fundamental cognitive skills in the context of competitive sports. Furthermore, there may be both sport-specific and sport-general cognitive enhancements derived from competitive sport training. The computer-based test also may have been influenced by a possible video game experience (Dye, Green, \& Bavelier) commonly experienced by this age group that may have occurred despite the research team having received assurances that no subjects were familiar with the experimental test.

\section{Conclusion}

The present study aimed to verify whether the relative age effect influences the cognitive abilities of reaction time and movement time of elite soccer athletes in the under 13 years of age category in Minas Gerais. The results showed that for this population the time of birth was not related to superior performance in tests that evaluate processing and movement time of athletes.

\section{References}

Augste, C., \& Lames, M. (2011). The relative age effect and success in German elite under 17 Soccer teams. Journal of Sports Sciences, 29, 983-987.

Carling, C., Legall, F., Reilly, T., \& Williams, A.M. (2009). Do anthropometric and fitness characteristics vary according to birth date distribution in elite youth academy soccer players? Scandinavian Journal of Medicine and Science in Sports, 19, 3-9.

Costa, I.T., Albuquerque, M.R., \& Garganta, J. (2012). Relative age effect in Brazilian soccer players: a historical analysis. International Journal of Performance Analysis in Sport, 12, 563-570.

Costa, I.T., Garganta, J., Greco, P.J., Mesquita, I. \& Seabra, A. (2010). Influence of Relative Age Effects and Quality of Tactical Behaviour in the Performance of Youth Soccer Players. International Journal of Performance Analysis of Sport, 10, 82-97.

Costa, V.T., Simim, M.A., Noce, F., Costa, I.T.; Samulski, D.M. \& Moraes, L.C.C.A. (2009). Comparison of relative age of elite athletes participating in the 2008 Brazilian soccer championship series A and B. Motricidade, 5, 35-38.

Cobley, S., Schorer, J. \& Baker, J. (2008). Relative age effects in professional German soccer: A historical analysis. Journal of Sports Sciences, 26, 1531-1538.

Delorme, N., Boiché, J. \& Raspaud, M. (2010). Relative age effect in elite sports: Methodological bias or real discrimination? European Journal of Sport Science, 10, 91-96.

Delorme, N. \& Raspaud, M. (2010). Relative age and dropout in French male soccer. Journal of Sports Sciences, 28, 717-722.

Delorme, N. \& Raspaud, M. (2009). The relative age effect in young French basketball players: a study on the whole population. Scandinavian Journal of Medicine and Science in Sports, 19, 235-242.

Dogan, B. (2009). Multiple-choice reaction and visual perception in female and male elite athletes. Journal of Sports Medicine and Physical Fitness, 49, 91-96.

Dorsch, F., Häcker, H.E., \& Stapf, K.H. (2004). Dicionário de Psicologia (Dictionary of Psychology) ( $2^{\text {nd }}$ Ed). Petrópolis, RJ: Editora Vozes.

Dye, M., Green, S. \& Bavelier, D. (2009). Increasing speed of processing with action video games. Current Directions in Psychological Science, 18, 321-326.

Edgar, S., \& O'Donoghue, P. (2006). Season of birth distribution of elite tennis players. Journal of Sport Sciences, 23, 1013-1020.

Gil, S., Ruiz, F., Irazusta, A., Gil, J., \& Irazusta, J. (2007). Selection of Young soccer players in terms of anthropometric and physiological factors. Journal of Medicine Physiology and Fitness, 47, 25-32.

Glamser, F. D., \& Vicent, J. (2004). The relative age effect among elite American youth soccer players. Journal of Sport Behavior, 17, 31-39.

Harbin, G., Durst, L., \& Harbin, D. (1989).Evaluation of oculomotor response in relationship to sports performance. Medicine and Science in Sports and Exercise, 21, 258-272.

Helsen, W.F., Hodges, N.J., Winckel, J.V., \& Starkes, J.L. (2000). The role of talent, physical precocity and practice in the development of soccer expertise. Journal of Sports Sciences, 18, 727-736. 
Helsen, W.F., Winckel, J.V., \& Williams, M. (2005). The relative age effect in youth soccer across Europe. Journal of Sport Sciences, 23, 629-636.

Hirose, N. (2009). Relationships among birth-month distribution, skeletal age and anthropometric characteristics in adolescent elite soccer players. Journal of Sports Sciences, 27, 1159-1166.

Hirose, N. (2011). Prediction of talent in youth soccer players: prospective study over 4-6 years. Football Science, 8, 1-7.

Hirose, N., Hirano, A., \& Fukubayashi, T. (2004). Biological maturity and choice reaction time in Japanese adolescent soccer players. Research in Sports Medicine, 12, 45-58.

Jiménez, I.P. \& Pain, M.T.G. (2008). Relative age effect in Spanish association football: its extent and implications for wasted potential. Journal of Sports Sciences, 26, 995-1003.

Jullien, H., Turpin, B., \& Carling, C. (2008). Influence of birth date on the career of French professional soccer players, Science \& Sports, 23, 149-155.

Magill, R.A. (2000). Motor learning: concepts and applications. Boston: WCB McGraw-Hill.

Montes-micó, R., Bueno, I., Candel, J., \& Pons, A.M. (2000). Eye -hand and eye-foot visual reaction times of Young soccer players. Optometry, 71, 775-780.

Mujika, I., Vayens, R., Matthys, S.P.J., Santisteban, J., Goiriena, J., \& Philippaerts, R. (2009). The relative age effect in a professional football club setting. Journal of Sports Sciences, 27, 1153-1158.

Musch, J., \& Grondin S. (2001). Unequal competition as an impediment to personal development: A review of the relative age effect in sport. Developmental Review, 21, 147- 167.

Musch, J., \& Hay, R. (1999). The relative age effect in soccer: Cross-cultural evidence for a systematic discrimination against children born late in the competition year. Sociologyof Sport Journal, 16, 54-64.

Noce, F., Ferreira, T.S., Moreira, C.Z., Andrade, G.P., De Mello, M.T., \& Costa, V.T. (2012). Influência do tempo de reação simples na seleção de jovens talentos no tênis (Influence of simple reaction time in the selection of young talents in tennis). Revista da Educaçãofísica (UEM), 23(3), 369-377.

Nougier, V., Stein, J.F., \& Bonnel, A.M. (1991). Information processing in sport and orienting of attention. International Journal of Sport Psychology, 22, 307-327.

Penna, E.M., \& Moraes L.C.C.A. (2010). Efeito relativo da idade em atletas brasileiros de futsal de alto nível (Relative age effect in Brazilian athletes high-level futsal). Motriz, 16, 658-663.

Penna, E.M., Santos, B.S., Ferreira, R.M., Costa, V.T., \& Moraes, L.C.C.A. (2012). Relação entre o mês de nascimento e a estatura de atletas do mundial de futebol sub 17 (Relationship between the month of birth and stature of world athletes 17). Revista Brasileira de Cineantropometria e Desempenho Humano (Brazilian Journal of Kineantropometry and Human performance), 14, 571-581.

Reilly, T., Bangsbo, J.,\& Franks, A. (2000). Anthropometric and physiological predispositions for elite soccer. Journal of Sports Sciences, 18, 669-683.

Romann, M., \& Fuchslocher, J. (2013). Relative age effects in Swiss junior soccer and their relationship with playing position, European Journal of Sport Science, 13, 356-363.

Ruschel, C., Haupenthal, A., Hubert, M., Fontana, H.B., Pereira, S.M., \& Roesler, H. (2011). Tempo de reação simples de jogadores de futebol de diferentes categorias e posições (Simple reaction time of football players of different categories and positions). Motricidade, 7, 73-82.

SchmidT, R., \& Wrisberg, C. (2010) Aprendizagem e Performance Motora (Motor learning and Performance). Porto Alegre, RS: Artmed.

Sheppard, J.M., \& Young, W.B. (2006). Agility literature review: classifications, training and testing. Journal of Sports Sciences, 24, 919-932.

Sherar, L.B., Baxter-Jones, A.D.G., Faulkner, R.A., \& Russel, K.W. (2007). Do physical maturity and birth date predict talent in male youth ice hockey players? Journal of Sports Sciences, 25, 879-886.
Simmons, C., \& Paull, G.C. (2001). Season-of-birth bias in association football. Journal of Sports Sciences, 19, 677-686.

Spierer, D.K., Petersen, R.A., \& Duffy, K. (2011). Response Time To Stimuli In Division I Soccer Players. Journal of Strength and Conditioning Research, 25, 1134-1141.

Vaeyens, R., Philippaerts, R.M., \& Malina, R.M. (2005). The relative age effect in soccer: A match-related perspective. Journal of Sports Science, 23, 747-756.

Vänttinen, T., Blonqvist, M., Luhtanen, P., \& Häkkinen, K. (2010). Effects of age and soccer expertise on general tests of perceptual and motor performance among adolescent soccer players. Perceptual and Motors Skills, 110, 675-692.

Vestberg, T., Gustafson, R., Maurex, L., Ingvar, M., \& Petrovic, P. (2012). Executive Functions Predict the Success of Top-Soccer Players. PLoS ONE, 7, e34731.

Voss, M.W., Kramer, A.F., Basak, C., Prakash, R.S., \& Roberts, B. (2010). Are expert athletes "expert" in the cognitive laboratory? A meta-analytic review of cognition and sport expertise. Applied Cognitive Psychology, 24, 812-826.

\section{Authors' note}

Eduardo Macedo Penna has a master's degree in Sport Sciences, is na assistant professor at the Federal University of Pará (Universidade Federal do Pará, UFPA).

Marco Tulio de Mello has a doctoral degree in psychobiology, is an associate professor of the Departament of Psychobiology at the Federal University of São Paulo (Universidade Federal de São Paulo, UNIFESP).

Renato Melo Ferreira has a doctoral degree in Sport science, is na adjunct professor at the Federal University of Ouro Preto (Universidade Federal de Ouro Preto, UFOP).

Luiz Carlos Couto de Albuquerque Moraes and Varley Teoldo da Costa have doctoral degrees in Sport science, and are adjunct professor in physical education course of the Federal University of Minas Gerais (Universidade Federal de Minas Gerais, UFMG).

\section{Corresponding author}

Eduardo Macedo Penna

Universidade Federal do Pará, campus Castanhal

Av. Dos Universitários s/n, Jaderlândia, Castanhal, PA 68750-000

E-mail: eduardomp@ufpa.br

Manuscript received on February 2, 2014

Manuscript accepted on February 12, 2015

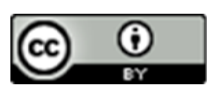

Motriz. The Journal of Physical Education. UNESP. Rio Claro, SP, Brazil - eISSN: 1980-6574 - under a license Creative Commons - Version 3.0 